\title{
LIFE TABLE PARAMETERS AND CONSUMPTION RATE OF Cydnodromus picanus Ragusa, Amblyseius graminis Chant, AND Galendromus occidentalis (Nesbitt) ON AVOCADO RED MITE Oligonychus yothersi (McGregor) (ACARI: PHYTOSEIIDAE, TETRANYCHIDAE)
}

\author{
Tommy Rioja S..$^{*}$, and Robinson Vargas M. ${ }^{2}$
}

\begin{abstract}
The avocado red mite Oligonychus yothersi (McGregor) is the major leaf pest in Chile's avocado orchards. It affects leaf physiology and makes it necessary to seek new natural enemies to interact with low population densities of $O$. yothersi. The potentiality of three predator mites: Cydnodromus picanus Ragusa, Amblyseius graminis Chant, and Galendromus occidentalis (Nesbitt) was evaluated under laboratory conditions $\left(27 \pm 1.93{ }^{\circ} \mathrm{C}, 87 \pm 3.61 \%\right.$ H.R. and 16:8 (L:D) photoperiod) on avocado leaf disks Persea americana Mill. var. Hass ( $\varnothing=5 \mathrm{~cm})$ by separately feeding eggs, immature, and adult females of $O$. yothersi, and registering postembryonic development, consumption, as well as life table parameters. The postembryonic development of $C$. picanus was significantly lower (5.46 days) compared to both A. graminis (7.33 days) and G. occidentalis (8.69 days) which were fed with immature O. yothersi. The life table parameters of $C$. picanus were net reproductive rate $\mathrm{R}_{0}=25.41$, finite rate of increase $\lambda=1.29$, and mean generation time $\mathrm{T}=12.46$. The net intrinsic rate of increase $\left(\mathrm{r}_{\mathrm{m}}\right)$ was significantly higher for $C$. picanus $\left(\mathrm{r}_{\mathrm{m}}=\right.$ 0.25 ) in contrast with $G$. occidentalis $\left(r_{m}=0.19\right)$, while A. graminis showed $r_{m}=-0.06$ indicating that its population didn't have descendants. Under laboratory conditions, $\mathrm{r}_{\mathrm{m}}$ registered by $C$. picanus is an indicator of its predatory potential to control $O$. yothersi. It can be assumed that the pest population reduction pattern could be maintained under field conditions.
\end{abstract}

Key words: postembryonic development, predation, pollen, biological control.

\section{INTRODUCTION}

The avocado, Persea americana Mill. (Lauraceae), is the second most cultivated fruit tree in Chile after vineyards, and covers an area of 39302.59 ha of which $56 \%$ is concentrated in the Valparaíso Region (INE, 2007). Furthermore, Chile is the second world exporter of avocados, mainly the Hass variety, with approximately 165000 t exported during the 2006-2007 season (Comité de Paltas, 2007).

Nevertheless, there is an economic loss associated with exports because of the presence of pests such as Pseudococcus longispinus (Targioni \& Tozzetti) (Hemiptera: Pseudococcidae), P. calceolariae (Maskell) (Hemiptera: Pseudococcidae), Hemiberlesia lataniae

${ }^{1}$ Universidad Pontificia Universidad Católica de Valparaíso, Facultad de Agronomía, Casilla 4-D, Quillota, Chile.

"Corresponding author (tommyriojasoto@yahoo.es).

${ }^{2}$ Instituto de Investigaciones Agropecuarias, Centro Regional de Investigación La Cruz, Casilla 3, La Cruz, Chile. (rvargas@inia.cl). Received: 17 January 2008.

Accepted: 19 May 2008.
(Signoret) (Hemiptera: Diaspidiae), and Heliothrips haemorrhoidalis (Bouché) (Thysanoptera: Thripidae) (SAG, 2007). The most important economic avocado pest at a foliar level is Oligonychus yothersi (McGregor) (Acari: Tetranychidae) (Altieri and Rojas, 1999), commonly known as the avocado red mite, and var. Hass is the most susceptible to be attacked by this tetraniquid. Oligonychus yothersi provokes a decrease in photosynthetic rate, stomatal conductance, and transpiration, negatively affecting the physiology of the avocado leaves (Schaffer et al., 1986). This has a direct consequence on the quality of the fruit and crop yield (Palevsky et al., 2007a), the same as for O. perseae Turttle, Baker and Abbatiello (Acari: Tetranychidae) found in California, USA (Kerguelen and Hoddle, 2000; Takano-Lee and Hoddle, 2002).

The natural enemies associated with $O$. yothersi in avocado orchards in the Province of Quillota are Stethorus histrio Chazeau (Coleoptera: Coccinellidae) and Oligota pygmaea Solier (Coleoptera: Staphylinidae), densitydependent generalist predators. Both coleoptera present natural colonization in the orchard only when the pest population increases (Obrycki and Kring, 1998; Kishimoto, 
2003) without exerting the necessary regulation to avoid damage produced by the red mite at the leaf physiological level. This makes it necessary to incorporate new predators to the system to interact with low $O$. yothersi population densities in the Chilean avocado orchards managed with biological control agents.

The most important predators of phytophagous mites in the world belong to the Phytoseiidae (Shrewsbury and Hardin, 2003) family which are easily adaptable to perturbed habitats and intensely managed as is the case of fruit orchards (Croft and Luh, 2004). The generalist species do not require large mite pest population densities to be established in an orchard, and migrate to other places through aerial dispersion if they lack prey (Colfer et al., 2003; Tixier et al., 2006). In the absence of phytophagous mites, the generalists have the capacity to use food alternatives such as pollen grains, fungi spores, insects in the immature stages, plant nectar, and exudates (Croft et al., 2004; Nomikou et al., 2005; Bouras and Papadoulis, 2005).

To include new natural enemies in a biological control system, it is fundamental to know their biological and ecological characteristics. The potential of the predators on their prey (De Vis et al., 2006b) can be estimated through population models and the construction of life tables, thus obtaining data about survival, longevity, reproduction, and descendants of the arthropod populations (Yu et al., 2005; Gabre et al., 2005; Yang and Chi, 2006; Ozman-Sullivan, 2006; Ferrero et al., 2007). Food quality has a great influence on the formulation of biological parameters since it is indispensable to recognize the predator's consumption in each stage of the pest in order to predict its effectiveness as a natural enemy (Kishimoto, 2003; Gotoh et al., 2006; Collier et al., 2007), and potential impact on the prey (Hosseini et al., 2005).

This study evaluated the demographic parameters and the consumption of Cydnodromus picanus, Amblyseius graminis, and Galendromus occidentalis on distinct stages of $O$. yothersi, first under laboratory conditions to identify the red mite's potential predators which would eventually be included in integrated pest management plans.

\section{MATERIALS AND METHODS}

Species studied. Three phytoseiid species were selected and evaluated as potential predators of the avocado red mite based on biological and ecological characteristics. Cydnodromus picanus Ragusa (Parasitiforms: Phytoseiidae) is a type III generalist phytoseiid from the Pica zone (20 $15^{\prime}$ S; 69 $20^{\circ} \mathrm{W}$ ), Tarapacá Region (Ragusa et al., 2000) which is able to withstand great thermal oscillations during throughout the day with scarce environmental humidity, and survive food scarcity. Amblyseius graminis Chant (Parasitiforms: Phytoseiidae) is a type III generalist phytoseiid (Croft et al., 2004) collected on redstem stork's bill (Erodium cicutarium (L.) L’Hér.) (Geraniaceae) in avocado orchards in the La Cruz zone (32 $49^{\prime} \mathrm{S} ; 7^{\circ} 17^{\prime} \mathrm{W}$ ), Valparaíso Region. Galendromus (Metaseiulus) occidentalis (Nesbitt) (Parasitiforms: Phytoseiidae) is a type II specialist phytoseiid (Blackwood et al., 2004) collected on walnut trees (Juglans regia L.) (Juglandaceae) (Ragusa and Vargas, 2002) in Los Andes locality (32 $49^{\prime} \mathrm{S} ; 7^{\circ} 35^{\prime} \mathrm{W}$ ), Valparaíso Region, and is a known mite predator of the Oligonychus genus (Shrewsbury and Hardin, 2003).

Site and study materials. The life table and consumption assays were carried out in the laboratories of Instituto de Investigaciones Agropecuarias (INIA) La Cruz, Valparaíso Region, between January and September 2007. Using a data logger, the Petri dish micro-climatic conditions were registered inside the laboratory, thereby obtaining a temperature of $27 \pm 1.93{ }^{\circ} \mathrm{C}$, relative humidity of $87 \pm 3.61 \%$, and a 16:8 (L:D) photoperiod for all the assays. These micro-climatic conditions were used to register the maximum biological potential of the predatory species since these are susceptible to low humidity in the egg stage (De Vis et al., 2006a). The experimental observations were carried out every 24 $\mathrm{h}$ with a $40 \mathrm{X}$ stereoscopical magnifying glass (Zeiss, Stemi, Göttingen, Germany). An adhesive (Point sticken blue, Point Chile S.A.) was used to avoid the mites from escaping.

Breeding of the avocado red mite. Oligonychus yothersi were bred massively on avocado leaves var. Hass, with a modified methodology (Oliveira et al., 2001) using plastic containers $(29 \times 7 \times 39.5 \mathrm{~cm})$ at a temperature of $27 \pm 2{ }^{\circ} \mathrm{C}$, relative humidity of $50 \pm 10 \%$, and a $16: 8$ (L:D) photoperiod. The micro-climatic conditions were registered with a digital thermo-hygrometer.

Phytoseiid breeding. The three predatory species selected were obtained in the phytoseiid breeding room located in the INIA La Cruz facilities. Subsequently, gravid females of this species were moved to the assay laboratory where they were bred on avocado leaf disks var. Hass infested with $O$. yothersi inside plastic containers (57 $\mathrm{x} 42 \times 19 \mathrm{~cm}$ ) opened at the top and covered with muslin to avoid contamination of the predatory mite populations. The assays were carried out with eggs laid by the firstgeneration females.

Postembryonic development.Egg-adult development was determined for each species of phytoseiid. Thirty gravid females were taken from each species and each female was placed inside an avocado leaf disk var. 
Hass $(\varnothing=5 \mathrm{~cm})$ confined with adhesive (sticken). They were eliminated after 5 h, leaving 1 egg per disk (1 egg = 1 replicate), and registering the duration of each developmental stage of the phytoseiid through the exuvium. Longevity of unmated individuals was obtained by making available, on a daily basis, ten 24-h-old eggs, 10 mobile immature individuals (protonymphs and deutonymphs), and five $O$. yothersi adult females. Daily consumption was registered for each phytoseiid.

Avocado (Persea americana Mill.) (Lauraceae) var. Hass and hairy brassica (Hirschfeldia incana (L.) Lagr.Foss.) (Brassicaceae) pollen was evaluated as alternative food to verify the survival of the species when facing a scarcity of prey. Daily, avocado var. Hass and $H$. incana pollen was provided separately by means of a fine brush, along with registering postembryonic development and predator longevity. Water was provided by cotton threads through a hole in the leaf for assays with pollen, as well as for those without food supply.

Fertility and longevity. Thirty females of known age were placed in avocado var. Hass leaf disks (1 female $=1$ replicate), integrating a male for $24 \mathrm{~h}$ every 7 days. Each female was given 15 mobile immature $O$. yothersi (protonymphs and deutonymphs). The phytoseiid eggs were counted and eliminated, recording longevity, fecundity, and consumption of the gravid females. To obtain descendants and the proportion of sexes, 10 females were randomly selected from the previous 30 . Thus, the eggs of each female were counted and deposited on 10 infested Petri dishes with all the $O$. yothersi stage, respectively, thus recording data about fertility and proportion of sexes for the females of each species.

Statistical analysis. A completely random design was applied with 30 replicates per experiment. Postembryonic development, longevity, and consumption data were transformed by $\sqrt{\mathrm{x}+0.5}$ (Steel and Torrie, 1985). Subsequently, ANOVA and Tukey test $(\mathrm{p}<0.05)$ were applied to evaluate the influence of food on postembryonic development and phytoseiid consumption.

The following were the calculated life table parameters (SAS Institute, 2007): (1) Net reproductive rate, $R_{0}=$ $l_{x} m_{x}$, being the number of females that produce a female during a generation or during their lifespan (Rabinovich, 1980); (2) intrinsic rate of increase, $r_{m}$ being the maximum exponential multiplication rate of a whole population, and calculated as $1=\quad l_{x} m_{x} \exp \left(-\mathrm{r}_{\mathrm{m}}\right)($ Birch, 1948); (3) finite rate of increase, $\lambda=\exp \left(r_{m}\right)$ being the number of females that produce one female per day (Birch, 1948); and (4) generation time, $\mathrm{T}=\quad \mathbf{X} l_{x} m_{x} / \mathrm{R}_{0}$ being the time that passes between first and next generation oviposition (Rabinovich, 1980).

The Jacknife nonparametric resampling method was used to compare the parameters of the life table between species, estimating the mean, variance, and standard error (Meyer et al., 1986; La Rossa and Kahn, 2003) with the LIFETABLES software, SAS (Maia et al., 2000), and SAS ${ }^{\circledR}$ (SAS Institute, 2007). The biological parameters were subsequently compared with the Tukey test $(\mathrm{P}<0.05)$.

\section{RESULTS}

The time of postembryonic development of $C$. picanus observed was less compared to the other two predatory species $(F=134.54, \mathrm{df}=2, \mathrm{p}<0.01)$ when fed mobile immature $O$. yothersi (Table 1). With regard to the longevity of phytoseiids fed with mobile immature O. yothersi, C. picanus showed a greater duration of the adult stage than $A$. graminis and $G$. occidentalis, thus indicating that the supply of $O$. yothersi protonymphs and deutonyphs had a positive influence on the postembryonic development of $C$. picanus $(F=167.30, \mathrm{df}=2, \mathrm{p}<0.01)$. In relation to the percentage of immature phytoseiids that developed to the adult stage, a survival rate of $100 \%$ was registered for C. picanus, $86 \%$ for $G$. occidentalis, and only $10 \%$ for A. graminis.

By feeding $O$. yothersi eggs, the postembryonic development of C. picanus and A. graminis increased with respect to the predators fed with immature red mites, whereas $G$. occidentalis only reached the larval stage. Furthermore, C. picanus showed a $13 \%$ survival rate and A. graminis $6.6 \%$ in the immature stage (Table 1 ). It was confirmed that in the immature stage, C. picanus, A. graminis, and $G$. occidentalis do not consume adult females of the avocado red mite (Table 1).

Using avocado var. Hass pollen, the duration of the postembryonic development was found to be shorter for A. graminis than $C$. picanus $(F=27.55$, $\mathrm{df}=1$, $\mathrm{p}<$ $0.01)$. Regarding longevity of the evaluated species, $A$. graminis individuals were significantly more long-lived $(F=148.18, \mathrm{df}=1, \mathrm{p}<0.0001)$ than $C$. picanus. Survival of immature phytoseiids that reached the adult stage was not significantly different between $A$. graminis (66.6\%) and C. picanus $(43.3 \%)(F=3.38, \mathrm{df}=1, \mathrm{p}=0.0713)$, though $G$. occidentalis did not consume pollen and only developed to the larval stage (Table 2).

Using $H$. incana pollen, egg-adult development was observed to be less for $A$. graminis than C. picanus $(F=177.21, \mathrm{df}=1, \mathrm{p}<0.01)$, although longevity was significantly greater for $A$. graminis $(F=345.48, \mathrm{df}=1$, $\mathrm{p}<0.0001)$ than C. picanus. Furthermore, A. graminis showed a $60 \%$ survival rate of individuals in the immature stage that developed into the adult stage, whereas $C$. picanus registered a statistically similar $46.6 \%(F=1.05$, $\mathrm{df}=1, \mathrm{p}=0.3087)($ Table 2).

In terms of C. picanus longevity, a significant difference was obtained for the individuals fed with mobile immature 
Table 1. Duration of postembryonic development and longevity (in days) of Cydnodromus picanus, Amblyseius graminis, and Galendromus occidentalis fed with Oligonychus yothersi in different stages.

\begin{tabular}{|c|c|c|c|c|c|c|c|}
\hline \multirow[b]{2}{*}{ Daily diet } & \multirow[b]{2}{*}{ State } & \multicolumn{6}{|c|}{ Phytoseiid species (mean \pm SE) } \\
\hline & & $\mathbf{n}$ & C. picanus & $\mathbf{n}$ & A. graminis & $\mathbf{n}$ & G. occidentalis \\
\hline 10 & Egg & 30 & $2.00 \pm 0.00 \mathrm{~b}$ & 30 & $2.00 \pm 0.00 \mathrm{~b}$ & 30 & $3.00 \pm 0.00 \mathrm{a}$ \\
\hline mobile immature & Larva & 30 & $1.00 \pm 0.00 \mathrm{~b}$ & 30 & $1.00 \pm 0.00 \mathrm{~b}$ & 30 & $2.10 \pm 0.00 \mathrm{a}$ \\
\hline \multirow[t]{4}{*}{ O. yothersi } & Protonymph & 30 & $1.03 \pm 0.03 b$ & 28 & $2.07 \pm 0.18 a$ & 26 & $1.69 \pm 0.09 \mathrm{a}$ \\
\hline & Deutonymph & 30 & $1.60 \pm 0.09 \mathrm{~b}$ & 15 & $2.60 \pm 0.13 a$ & 26 & $1.92 \pm 0.10 \mathrm{~b}$ \\
\hline & Egg-Adult & 30 & $5.46 \pm 0.10 \mathrm{c}$ & 3 & $7.33 \pm 0.33 b$ & 26 & $8.69 \pm 0.16 \mathrm{a}$ \\
\hline & Adult (longevity) & 30 & $60.03 \pm 1.54 \mathrm{a}$ & 3 & $18.00 \pm 2.08 \mathrm{c}$ & 26 & $29.08 \pm 1.17 b$ \\
\hline 10 & Egg & 30 & $2.00 \pm 0.00 \mathrm{~b}$ & 30 & $2.00 \pm 0.00 b$ & 30 & $3.00 \pm 0.00 \mathrm{a}$ \\
\hline O. yothersi & Larva & 30 & $1.00 \pm 0.00 \mathrm{~b}$ & 30 & $1.00 \pm 0.00 b$ & 30 & $2.07 \pm 0.11 \mathrm{a}$ \\
\hline \multirow[t]{4}{*}{ eggs } & Protonymph & 29 & $2.89 \pm 0.12 b$ & 21 & $3.80 \pm 0.29 a$ & 0 & - \\
\hline & Deutonymph & 10 & $3.90 \pm 0.31 \mathrm{a}$ & 7 & $3.00 \pm 0.30 \mathrm{a}$ & 0 & - \\
\hline & Egg-Adult & 4 & $9.09 \pm 0.62 \mathrm{a}$ & 2 & $9.50 \pm 0.50 \mathrm{a}$ & 0 & - \\
\hline & Adult (longevity) & 4 & $19.75 \pm 2.42 \mathrm{a}$ & 2 & $9.50 \pm 1.50 \mathrm{~b}$ & 0 & - \\
\hline 5 & Egg & 30 & $2.00 \pm 0.00 \mathrm{~b}$ & 30 & $2.00 \pm 0.00 \mathrm{~b}$ & 30 & $3.00 \pm 0.00 \mathrm{a}$ \\
\hline \multirow{5}{*}{$\begin{array}{l}\text { O. yothersi } \\
\text { adult females }\end{array}$} & Larva & 30 & $1.00 \pm 0.00 \mathrm{~b}$ & 30 & $1.00 \pm 0.00 \mathrm{~b}$ & 30 & $2.40 \pm 0.09 \mathrm{a}$ \\
\hline & Protonymph & 30 & $4.66 \pm 0.08 \mathrm{a}$ & 8 & $2.68 \pm 0.13 b$ & 0 & - \\
\hline & Deutonymph & 0 & - & 0 & - & 0 & - \\
\hline & Egg-Adult & 0 & - & 0 & - & 0 & - \\
\hline & Adult (longevity) & 0 & - & 0 & - & 0 & - \\
\hline
\end{tabular}

Values with distinct letters in the row indicate significant differences according to Tukey $(\mathrm{p}<0.05)$.

SE: standard error. n: number of individuals.

red mites (60.03 days) as compared with administering an exclusive diet of avocado var. Hass pollen (40.46 días) ( $F$ $=62.74, \mathrm{df}=1, \mathrm{p}<0.0001)$ and $H$. incana $(22.5$ días $)(F=$ $251.41, \mathrm{df}=1, \mathrm{p}<0.0001)$, thus indicating that these two latter diets are a feeding alternative when prey is scarce. On the other hand, A. graminis registered a significantly greater longevity when fed avocado var. Hass pollen (78.10 días) $(F=91.36, \mathrm{df}=1, \mathrm{p}<0.10001)$ and $H$. incana (84.94 días) $(F=86.85, \mathrm{df}=1, \mathrm{p}<0.0001)$ compared with feeding on mobile immature red mites (18 days) (Table 1 , Table 2).

On a water diet, C. picanus and A. graminis developed up to the protonymph stage. In contrast, G. occidentalis only reached the larval stage. Furthermore, C. picanus showed a longer duration in the protonymph stage compared with A. graminis $(F=1158.03, \mathrm{df}=1, \mathrm{p}<0.01)$ (Table 2).

As for depredation on immature O. yothersi, G. occidentalis registered consumption of the avocado red mite in the larval stage although $C$. picanus and A. graminis did not present depredation in this stage $(F=457.40, \mathrm{df}=2$, $\mathrm{p}<0.01$ ), indicating that $G$. occidentalis needs to be fed to continue its postembryonic development. On the other hand, C. picanus and $G$. occidentalis registered less depredation in the protonymph stage than A. graminis $(F=32.58$, df $=$
2, $\mathrm{p}<0.01$ ), a behavior also observed in deutonymphs ( $F=$ 13.77, $\mathrm{df}=2, \mathrm{p}<0.01$ ). Nevertheless, unmated $C$. picanus adults showed a greater depredation rate compared with unmated A. graminis and $G$. occidentalis adults $(F=71.96$, $\mathrm{df}=2, \mathrm{p}<0.01)$ (Table 3).

Agreater depredation rate of mated A. graminis females on immature $O$. yothersi was observed as compared with C. picanus and G. occidentalis $(F=306.67, \mathrm{df}=2$, $\mathrm{p}<$ 0.01) (Table3).

\section{Life table parameters}

Cydnodromus picanus females showed gradual mortality over time in contrast with A. graminis and $G$. occidentalis which concentrated almost $80 \%$ mortality in 7 days (Figure 1). Furthermore, greater longevity was noted for A. graminis (25.7 days) and C. picanus (25.43 days) females in contrast with $G$. occidentalis (22.56 days $)(F=5.44, \mathrm{df}=2, \mathrm{p}=0.006)$. The three survival curves recorded for the distinct species were type I, thus indicating that mortality was mainly concentrated in longlived individuals (Rabinovich, 1980).

There is no significant difference in the oviposition rate between the evaluated phytoseiid species $(\mathrm{F}=1.47$, $\mathrm{df}=2, \mathrm{p}=0.236$ ) (Figure 2). Comparing female fertility, C. picanus had a higher value than G. occidentalis and 
Table 2. Influence of diet on duration of postembryonic development and longevity (in days) of Cydnodromus picanus, Amblyseius graminis, and Galendromus occidentalis.

\begin{tabular}{|c|c|c|c|c|c|c|c|}
\hline \multirow[b]{2}{*}{ Daily diet } & \multirow[b]{2}{*}{ State } & \multicolumn{6}{|c|}{ Phytoseiid species (mean \pm SE) } \\
\hline & & $\mathrm{S}^{1}(\%)$ & C. picanus & S (\%) & A. graminis & $\mathrm{S}(\%)$ & G. occidentalis \\
\hline \multirow{6}{*}{$\begin{array}{l}\text { Persea americana } \\
\text { var. Hass pollen }\end{array}$} & Egg & 100a & $2.00 \pm 0.00 \mathrm{~b}$ & 100a & $2.00 \pm 0.00 \mathrm{~b}$ & $100 a$ & $3.00 \pm 0.00 \mathrm{a}$ \\
\hline & Larva & $100 \mathrm{a}$ & $1.00 \pm 0.00 \mathrm{~b}$ & 100a & $1.00 \pm 0.00 \mathrm{~b}$ & $100 \mathrm{a}$ & $1.13 \pm 0.06 \mathrm{a}$ \\
\hline & Protonymph & $96.6 \mathrm{a}$ & $4.37 \pm 0.18 \mathrm{a}$ & $66.6 b$ & $2.40 \pm 0.13 b$ & $0 \mathrm{c}$ & - \\
\hline & Deutonymph & $73.3 \mathrm{a}$ & $3.50 \pm 0.20 \mathrm{a}$ & $66.6 \mathrm{a}$ & $2.40 \pm 0.21 b$ & $0 \mathrm{~b}$ & - \\
\hline & Egg-Adult & $43.3 \mathrm{a}$ & $10.86 \pm 0.52 \mathrm{a}$ & $66.6 \mathrm{a}$ & $7.80 \pm 0.26 \mathrm{~b}$ & $0 \mathrm{~b}$ & - \\
\hline & Adult (longevity) & $43.3 \mathrm{a}$ & $40.46 \pm 1.11 b$ & $66.6 \mathrm{a}$ & $78.10 \pm 2.37 \mathrm{a}$ & $0 \mathrm{~b}$ & - \\
\hline \multirow{6}{*}{$\begin{array}{l}\text { Hirschfeldia } \\
\text { incana } \\
\text { pollen }\end{array}$} & Egg & 100a & $2.00 \pm 0.00 \mathrm{~b}$ & 100a & $2.00 \pm 0.00 \mathrm{~b}$ & $100 \mathrm{a}$ & $3.00 \pm 0.00 \mathrm{a}$ \\
\hline & Larva & 100a & $1.00 \pm 0.00 \mathrm{~b}$ & 100a & $1.00 \pm 0.00 \mathrm{~b}$ & $100 \mathrm{a}$ & $1.03 \pm 0.03 \mathrm{a}$ \\
\hline & Protonymph & $93.3 \mathrm{a}$ & $2.67 \pm 0.14 \mathrm{a}$ & $60 \mathrm{~b}$ & $1.00 \pm 0.00 \mathrm{~b}$ & $0 \mathrm{c}$ & - \\
\hline & Deutonymph & $83.3 \mathrm{a}$ & $3.04 \pm 0.12 \mathrm{a}$ & $60 \mathrm{~b}$ & $1.05 \pm 0.05 b$ & $0 \mathrm{c}$ & - \\
\hline & Egg-Adult & $46.6 \mathrm{a}$ & $8.68 \pm 0.26 a$ & $60 \mathrm{a}$ & $5.05 \pm 0.05 b$ & $0 \mathrm{~b}$ & - \\
\hline & Adult (longevity) & $46.6 \mathrm{a}$ & $22.50 \pm 0.97 b$ & $60 \mathrm{a}$ & $84.94 \pm 2.85 \mathrm{a}$ & $0 \mathrm{~b}$ & - \\
\hline \multirow[t]{6}{*}{ Water } & Egg & $100 \mathrm{a}$ & $2 \pm 0.0 \mathrm{~b}$ & 100a & $2.00 \pm 0.00 \mathrm{~b}$ & $100 \mathrm{a}$ & $3.00 \pm 0.00 \mathrm{a}$ \\
\hline & Larva & $100 \mathrm{a}$ & $1 \pm 0.0 \mathrm{~b}$ & $100 \mathrm{a}$ & $1.00 \pm 0.00 \mathrm{~b}$ & $100 \mathrm{a}$ & $1.15 \pm 0.06 \mathrm{a}$ \\
\hline & Protonymph & $100 \mathrm{a}$ & $4.73 \pm 0.08 \mathrm{a}$ & $66.6 \mathrm{~b}$ & $1.10 \pm 0.06 \mathrm{~b}$ & $0 \mathrm{c}$ & - \\
\hline & Deutonymph & - & - & - & - & - & - \\
\hline & Egg-Adult & - & - & - & - & - & - \\
\hline & Adult (longevity) & - & - & - & - & - & - \\
\hline
\end{tabular}

Distinct letters indicate significant differences according to Tukey $(\mathrm{p}<0.05)$.

$\mathrm{S}^{1}$ : survival of individuals expressed in \%. SE: standard error. $\mathrm{n}$ : number of individuals.

A. graminis whose eggs were almost entirely infertile (Figure 3).

The life table parameters of the three phytoseiids fed with immature $O$. yothersi showed that $C$. picanus showed higher $\mathrm{R}_{0}, \mathrm{r}_{\mathrm{m}}$, and $\lambda$ than $G$. occidentalis $(F=233.58$, $\mathrm{df}=$ $3, \mathrm{p}<0.0001 ; F=2390.05, \mathrm{df}=3, \mathrm{p}<0.0001 ; F=215.61$, $\mathrm{df}=3, \mathrm{p}<0.0001 ; F=2127.12, \mathrm{df}=3, \mathrm{p}<0.0001)$, whereas A. graminis revealed $\mathrm{R}_{0}=0.27$ indicating that the population of this specie decreases over time (Table 4). The biological parameters of C. picanus show that the population grew 25.41 times in 12.46 days $(\mathrm{T})$, and for each female of the actual generation there will be 25.41 females in the next generation. Furthermore, for each female present on a given day, there will be almost 1.29 $(\lambda)$ females the next day. Therefore, at any particular point in time, the number of females in the $C$. picanus population will increase at such a rate that a population growth of $25 \%\left(\mathrm{r}_{\mathrm{m}}\right)$ is expected from one day to the next. Moreover, comparing $\mathrm{R}_{0}, \mathrm{r}_{\mathrm{m}}, \mathrm{T}$, and $\lambda$ of $C$. picanus with $O$. yothersi, it is observed that only the latter attains a higher $\mathrm{R}_{0}(F=233.58, \mathrm{df}=3, \mathrm{p}<0.0001)$, while the predator registered higher $r_{m}$ and $\lambda$. In addition, generation time was significantly lower for $C$. picanus $(F=215.61, \mathrm{df}=3$, $\mathrm{p}<0.0001$ ) demonstrating that it multiplied more rapidly than the red mite population (Table 4).

\section{DISCUSSION}

Consumption records during the postembryonic development of the three phytoseiids in the $O$. yothersi egg, immature, and adult female stages indicated that protonymphs and deutonymphs of the avocado red mite are differentially predated by C. picanus, A. graminis, and G. occidentalis. This influenced the depredation rate by, morphology, prey stage, and the predators' mouth parts (Croft et al., 2004), since the integuments of O. yothersi adult females are more difficult to penetrate than those of immature prey (Kishimoto y Takagi, 2001; Furuichi et al., 2005).

Regarding consumption, Ragusa et al. (2000) established that $C$. picanus fed with Tetranychus urticae C.L. Koch (Tetranychidae) eggs reach the adult stage in approximately 4 days, demonstrating a positive influence of this prey in the development of the phytoseiid compared with $O$. yothersi. This would be explained by $T$. urticae egg morphology: spherical and easy to handle by the phytoseiids. In contrast, $O$. yothersi eggs adhere to the surface of the avocado leaf making it difficult to capture, and consequently less attractive as food (Vantornhout, 2006). 


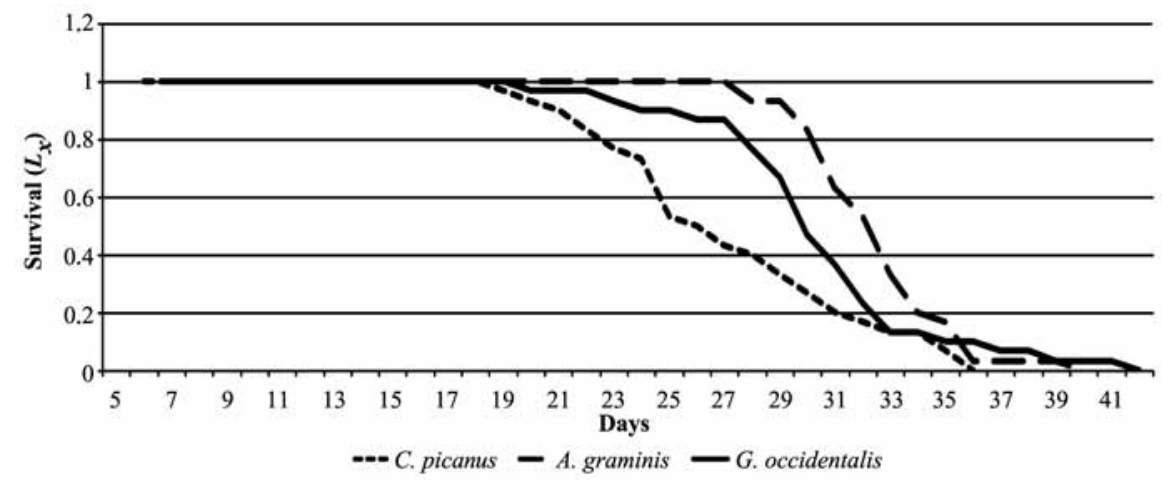

Figure 1. Survival curve of mated female Cydnodromus picanus, Amblyseius graminis, and Galendromus occidentalis fed with mobile immature Oligonychus yothersi.

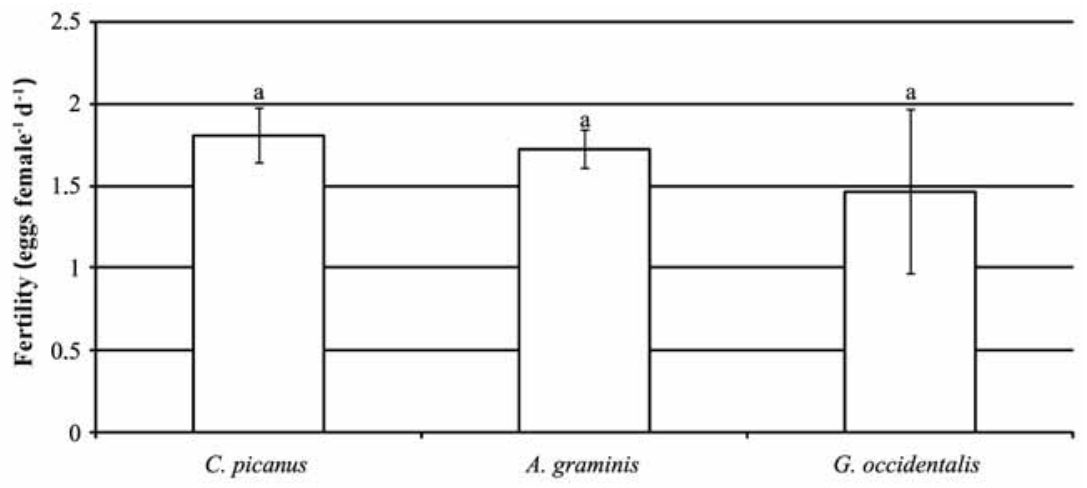

Phytoseiid species

Distinct letters indicate significant differences according to Tukey $(\mathrm{p}<0.05)$.

Figure 2. Female fertility of Cydnodromus picanus, Amblyseius graminis, and Galendromus occidentalis fed with mobile immature Oligonychus yothersi.

The established classification with regard to alternative food was confirmed by pointing out $C$. picanus and $A$. graminis as type III generalists and G. occidentalis as a recognized type II specialist preferring the Oligonychus genus (Shrewsbury and Hardin, 2003; Croft et al., 2004). Both generalists would be more adapted to conditions of food scarcity than $G$. occidentalis which need to feed on mites in order to develop. Ragusa et al. (2000) gave Oxalis sp. and Ricinus sp. pollen to C. picanus exhibiting survival rates of $52 \%$ and $44 \%$, respectively in the immature stage. When fed with avocado var. Hass pollen, $43.3 \%$ of the population survived, converting it into an ideal alternative food in the absence of the red mite, and demonstrating another comparative advantage over $G$. occidentalis. It is also worth mentioning that $G$. occidentalis in commercial orchards is easily displaced by type III generalist phytoseiids. Slow and smaller-sized, it can also be transformed into prey for phytoseiids, and easily depredated by coleopters belonging to the Stethorus and Oligota genera (Colfer et al., 2003). Therefore, possible field releases of $G$. occidentalis could only be carried out when the $O$. yothersi population is high in the orchard, without being able to avoid the physiological damage provoked by the red mite on avocado leaves.

When O. yothersi population density is low and within a context of habitat management, it would be possible to carry out preventive releases of $C$. picanus starting in September using $H$. incana pollen, as well as avocado pollen, as an alternative food, since this Brassicaceae is associated to avocado orchards in the Valparaíso Region and could be used as a refuge in hillside commercial plantations (Bouras and Papadoulis, 2005; Palevsky et al., 2007b).

Mated A. graminis females showed a high rate of total consumption, but their eggs were infertile with no descendants over time compared with $C$. picanus that hatched almost $100 \%$ of its eggs. Regarding this phenomenon, several authors have pointed out a likeness 
Table 3. Total consumption by Cydnodromus picanus, Amblyseius graminis, and Galendromus occidentalis of mobile immature Oligonychus yothersi during postembryonic development and longevity of predator mites.

\begin{tabular}{llrrr}
\hline & & \multicolumn{3}{c}{ Phytoseiid species (mean \pm SE) } \\
\cline { 3 - 5 } Prey & Phytoseiid state & \multicolumn{1}{c}{ C. picanus } & A. graminis & G. occidentalis \\
\hline Mobile immature & Larva & $0.00 \pm 0.00 \mathrm{~b}$ & $0.00 \pm 0.00 \mathrm{~b}$ & $1.73 \pm 0.10 \mathrm{a}$ \\
O. yothersi & Protonymph & $2.00 \pm 0.14 \mathrm{~b}$ & $4.17 \pm 0.32 \mathrm{a}$ & $2.34 \pm 0.11 \mathrm{~b}$ \\
& Deutonymph & $2.63 \pm 0.11 \mathrm{~b}$ & $3.93 \pm 0.38 \mathrm{a}$ & $2.50 \pm 0.12 \mathrm{~b}$ \\
& Unmated adult & $59.20 \pm 1.66 \mathrm{a}$ & $39.66 \pm 2.02 \mathrm{~b}$ & $34.88 \pm 1.34 \mathrm{~b}$ \\
& Mated female & $142.76 \pm 6.34 \mathrm{~b}$ & $298.53 \pm 7.44 \mathrm{a}$ & $90.30 \pm 3.49 \mathrm{c}$ \\
\hline
\end{tabular}

Values with different letters in the rows indicate significant differences according to Tukey $(\mathrm{p}<0.05)$.

SE: standard error.

Table 4. Life table parameters of the Cydnodromus picanus, Amblyseius graminis, Galendromus occidentalis predator mites, and the avocado red mite Oligonychus yothersi.

\begin{tabular}{lcccc}
\hline \multirow{2}{*}{$\begin{array}{l}\text { Biological } \\
\text { parameters }\end{array}$} & \multicolumn{4}{c}{ Species (mean \pm SE) } \\
\cline { 2 - 5 } & ${\text { C. } \text { picanus }^{1}}^{1}$ & ${\text { A. } \text { graminis }^{1}}^{1}$ & G. occidentalis $^{1}$ & O. yothersi \\
\hline $\mathrm{R}_{0}$ & $25.41 \pm 1.14 \mathrm{~b}$ & $0.27 \pm 0.01 \mathrm{~d}$ & $16.25 \pm 0.68 \mathrm{c}$ & $39.66 \pm 1.84 \mathrm{a}$ \\
$\mathrm{r}_{\mathrm{m}}$ & $0.25 \pm 0.00 \mathrm{a}$ & $-0.06 \pm 0.00 \mathrm{~d}$ & $0.19 \pm 0.00 \mathrm{c}$ & $0.22 \pm 0.00 \mathrm{~b}$ \\
$\mathrm{~T}$ & $12.46 \pm 0.16 \mathrm{~d}$ & $20.75 \pm 0.31 \mathrm{a}$ & $14.62 \pm 0.25 \mathrm{c}$ & $16.36 \pm 0.19 \mathrm{~b}$ \\
$\lambda$ & $1.29 \pm 0.00 \mathrm{a}$ & $0.93 \pm 0.00 \mathrm{~d}$ & $1.20 \pm 0.00 \mathrm{c}$ & $1.25 \pm 0.00 \mathrm{~b}$ \\
$\mathrm{n}$ & 30 & 30 & 30 & 25 \\
\hline
\end{tabular}

Values with different letters in the rows indicate significant differences according to Tukey $(\mathrm{p}<0.05)$.

${ }^{1}$ Daily diet $=15$ mobile immature $O$. yothersi. SE: standard error. n: number of individuals. $\mathrm{R}_{0}$ : net reproductive rate. rm: net intrinsic rate of increase.

T: mean generation time. $\lambda$ : finite rate of increase.

to sequestration or extraction of secondary metabolites from plants, that is, specialist phytophages such as $O$. yothersi would be extracting alelochemicals from the avocado which would then be stored in their bodies as a defense against their predators, thus affecting in distinct ways the three evaluated phytoseiid species (Aregullín and Rodríguez, 2003; Collier et al., 2007; Zhu-Salzman et al., 2008). For this reason, it is necessary to carry out studies to confirm the presence of these toxic substances found in the red mite and predators. On the other hand, phytophages that have a broad range of host plants do not have the capacity to extract these toxic substances (Trigo, 2000; Termonia et al., 2001). Nishida (2002) points out that these substances extracted from the plants are biochemically transformed before being stored in the bodies of lepidopters. It must also be mentioned that endosymbiontic fungi are present in the plants and influence the tri-trophic interactions (plant-pest-natural enemy), affecting predator development, survival, and reproduction for the production of toxic alkaloids (mycotoxins) (De Sassi et al., 2006).

It must be mentioned that studies evaluating predators based on consumption or female fertility rates do not determine a potential control of the pest and provide incomplete information. High consumption rates do not imply high female fertility and fecundity, since A. graminis showed higher consumption and an oviposition rate similar to C. picanus and G. occidentalis. However, evaluating fecundity, $C$. picanus had a higher mean of eggs able to develop to the adult stage. It is therefore necessary to determine key biological parameters in ideal conditions to observe the biotic potential of the species of interest.

Establishing life and fecundity tables of predators and prey are fundamental to evaluate the efficiency and potentiality of a natural enemy on a specific pest (Naranjo, 2001; Gabre et al., 2005; Vantornhout et al., 2005; OzmanSullivan, 2006; Collier et al., 2007; Reis et al., 2007; Ferrero et al., 2007; Broufas et al., 2007). The abovementioned information along with consumption registers generate assumptions of potential predator efficiency in the orchard (Chi and Yang, 2003; Kishimoto, 2003; Hosseini et al., 2005; Gotoh et al., 2006). This knowledge is relevant particularly for the assessment of natural enemies that are commercially produced (O’Neil et al., 1998).

In reference to the biological parameters, intrinsic rate of increase $\left(r_{m}\right)$ indicates the capacity of the population to multiply in one generation, relating net reproductive rate $\left(\mathrm{R}_{0}\right)$ on generation time (T) (Rabinovich, 1980), implying the potential control of a natural enemy on a specific 


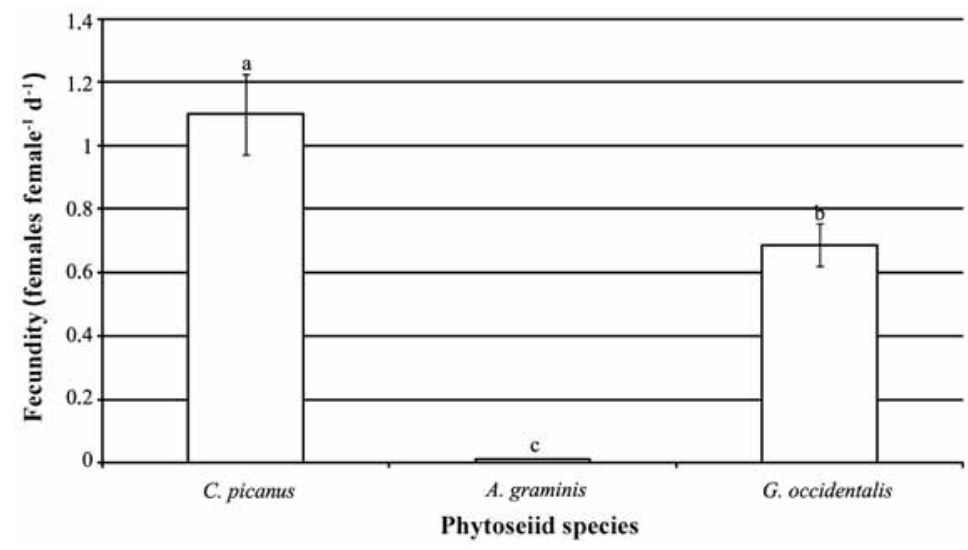

Distinct letters indicate significant differences according to Tukey $(\mathrm{p}<0.05)$.

Figure 3. Mean female fecundity of Cydnodromus picanus, Amblyseius graminis, and Galendromus occidentalis fed with mobile immature Oligonychus yothersi.

pest (Persad y Khan, 2002; Kontodimas et al., 2007). In theory, associating predator intrinsic rate of increase on the prey intrinsic rate of increase, shown by the equation $\mathrm{r}_{\mathrm{m}}$ predator $/ \mathrm{r}_{\mathrm{m}}$ pest $\geq 1$, will indicate an efficiency potential to regulate the pest population. Other important parameters must also be considered such as longevity, predatory capacity, and early prey detection ability in selecting efficient biological control (Fiaboe et al., 2007). Cydnodromus picanus achieved a higher $\mathrm{r}_{\mathrm{m}}$ than the red mite, signifying that this population has the capacity to control $O$. yothersi across generations, that is, this species of phytoseiid is an efficient natural enemy of the phytophage mite, and its potential use should be evaluated in the integrated management of avocado mites.

Regarding phytoseiid field releases, all the factors that can influence its effectiveness on a specific phytophage mite must be considered, such as domatia of the host plant (morphological structures of the leaf: depressions, tricomes, cavities between the midrib, and secondary veins that provide refuge for the predator mites generating mutualism) (Matos et al., 2004), chaetotaxia of the predator (length of the dorsoventral setae) (Croft et al., 2004), alternative food availability (Bouras and Papadoulis, 2005), host plant, and leaf area (Collier et al., 2007).

\section{CONCLUSIONS}

Given the phytoseiid species under evaluation: $C$. picanus, A. graminis, and G. occidentalis, it can be concluded that:

C. picanus and $G$. occidentalis complete their postembryonic development and are able to reproduce by feeding on immature avocado red mites in laboratory conditions, both considered as potential predators of
O. yothersi. However, G. occidentalis requires prey in the larval stage for its development and without using alternative food.

A. graminis has no descendants when feeding on mobile immature O. yothersi. However, its population could be increased in the orchard through a habitat management program since it survives by feeding on avocado var. Hass and $H$. incana pollen as alternative food.

A new predator-prey interaction was established under laboratory conditions (C. picanus-O. yothersi). Field releases in the spring of $C$. picanus upheld its potentiality as a predator of the avocado red mite in the context of Integrated Pest Management.

\section{RESUMEN}

Parámetros de tabla de vida y tasa de consumo de Cydnodromus picanus Ragusa, Amblyseius graminis Chant y Galendromus occidentalis (Nesbitt), sobre la arañita roja del palto Oligonychus yothersi (McGregor) (Acari: Phytoseiidae, Tetranychidae). En Chile la arañita roja del palto Oligonychus yothersi (McGregor) es la plaga más importante a nivel foliar en huertos comerciales afectando la fisiología de la hoja, siendo necesaria la búsqueda de nuevos enemigos naturales que interactúen a bajas densidades poblacionales de $O$. yothersi. Se evaluó en condiciones de laboratorio $(27 \pm$ $1,93{ }^{\circ} \mathrm{C}, 87 \pm 3,61 \%$ H.R. y un fotoperíodo de 16:8 (L: O)) sobre discos de hojas de palto (Persea americana Mill.) var. Hass $(\varnothing=5 \mathrm{~cm})$ la potencialidad de ácaros depredadores Cydnodromus picanus Ragusa, Amblyseius graminis Chant y Galendromus occidentalis (Nesbitt), suministrando huevos inmaduros y hembras adultas de $O$. yothersi separadamente, registrando desarrollo 
postembrionario, consumo y parámetros de tabla de vida. El desarrollo postembrionario de C. picanus fue significativamente menor (5,46 días) en comparación a A. graminis (7,33 días) y G. occidentalis (8,69 días) al ser alimentados con inmaduros de O. yothersi. Los parámetros de tabla de vida de $C$. picanus fueron tasa neta de reproducción $\mathrm{R}_{0}=25,41$, tasa finita de crecimiento $\lambda=$ 1,29 y tiempo generacional $\mathrm{T}=12,46$. La tasa intrínseca de crecimiento $\left(\mathrm{r}_{\mathrm{m}}\right)$ fue significativamente mayor para C. picanus $\left(\mathrm{r}_{\mathrm{m}}=0,25\right)$ frente a $G$. occidentalis $\left(\mathrm{r}_{\mathrm{m}}=\right.$ 0,19), mientras que A. graminis presentó una $r_{\mathrm{m}}=-0,06$ indicando que su población no tiene descendencia. El $r_{n}$ registrado por $C$. picanus en condiciones de laboratorio es un indicador del potencial que tiene como depredador sobre $O$. yothersi, y permite suponer que en condiciones de campo el patrón de reducción poblacional de la plaga podría mantenerse.

Palabras clave: desarrollo postembrionario, depredación, polen, control biológico.

\section{LITERATURE CITED}

Altieri, M., and A. Rojas. 1999. Ecological impacts of Chile's neoliberal policies, with special emphasis on agroecosystems. Environment, Development and Sustainability 1:55-72.

Aregullín, M., and E. Rodríguez. 2003. Sesquiterpene lactone sequestration by the tortoise beetle Physonota arizonae (Cassidinae). Revista de la Sociedad Química de México 47(2):143-145.

Birch, L.C. 1948. The intrinsic rate of natural increase of and insect population. J. Anim. Ecol. 17:15-26.

Blackwood, J.S., H.-K. Luh, and B.A. Croft. 2004. Evaluation of prey-stage preference as an indicator of life-style type in phytoseiid mites. Exp. Appl. Acarol. 33:261-280.

Bouras, S.L., and G.TH. Papadoulis. 2005. Influence of selected fruit tree pollen on life history of Euseius stipulatus (Acari: Phytoseiidae). Exp. Appl. Acarol. 36:1-14.

Broufas, G.D., M.L. Pappas, and D.S. Koveos. 2007. Development, survival, and reproduction of the predatory mite Kampimodromus aberrans (Acari: Phytoseiidae) at different constant temperatures. Environ. Entomol. 36(4):657-665.

Chi, H., and T. Yang. 2003. Two-Sex life table and predation rate of Propylaea japonica Thunberg (Coleoptera: Coccinellidae) fed on Myzus persicae (Sulzer) (Homoptera: Aphididae). Environ. Entomol. 32(2):327-333.
Colfer, R.G., J.A. Rosenheim, L.D. Godfrey, and C.L. Hsu. 2003. Interactions between the augmentatively released predaceous mite Galendromus occidentalis (Acari: Phytoseiidae) and naturally occurring generalist predators. Environ. Entomol. 32(4):840-852.

Collier, K.F., G.S. Albuquerque, J.O. de Lima, A. Pallini, and A.J. Molina-Rugama. 2007. Neoseiulus idaeus (Acari: Phytoseiidae) as a potential biocontrol agent of the two-spotted spider mite, Tetranychus urticae (Acari: Tetranychidae) in papaya: performance on different prey stage-host plant combinations. Exp. Appl. Acarol. 41:27-36.

Comité de paltas. 2007. Comité de paltas, Santiago, Chile. Available at http://paltahass.cl/html/mapa/index.htm (Accessed 11 December 2007).

Croft, B.A., J.S. Blackwood, and J.A. McMurtry. 2004. Classifying life-style types of phytoseiid mites: diagnostic traits. Exp. Appl. Acarol. 33:247-260.

Croft, B.A., and H.-K. Luh. 2004. Phytoseiid mites on unsprayed apple trees in Oregon, and other western states (USA): distributions, life-style types and relevance to commercial orchards. Exp. Appl. Acarol. 33:281-326.

De Sassi, C., C.B. Müller, and J. Krauss. 2006. Fungal plant endosymbionts alter life history and reproductive success of aphid predators. Proc. R. Soc. London, Ser. B 273:1301-1306.

De Vis, R.M., G.J. de Moraes, and M.R. Bellini. 2006a. Effect of air humidity on the egg viability of phytoseiid mites Acari: Phytoseiidae, Stigmaeidae common on rubber trees in Brazil. Exp. Appl. Acarol. 38:25-32.

De Vis, R.M., G.J. de Moraes, and M.R. Bellini. 2006b. Inicial screening of little known predatory mites in Brazil as potential pest control agents. Exp. Appl. Acarol. 39:115-125.

Ferrero, M., G. Moraes, S. Kreiter, M. Tixier, and M. Knapp. 2007. Life tables of the predatory mite Phytoseiulus longipes feeding on Tetranychus evansi at four temperatures (Acari: Phytoseiidae, Tetranychidae). Exp. Appl. Acarol. 41:45-53.

Fiaboe, K.K.M., M.G.C. Gondim Jr., G.J. de Moraes, C.K.P.O. Ogol, and M. Knapp. 2007. Bionomics of the acarophagous ladybird beetle Stethorus tridens fed Tetranychus evansi. J. Appl. Entomol. 131(5):355361.

Furuichi, H., K. Oku, S. Yano, A. Takafuji, and M. Osakabe. 2005. Why does the predatory mite Neoseiulus womersleyi Schicha (Acari: Phytoseiidae) prefer spider mite eggs to adults? Appl. Entomol. Zool. 40(4):675-678.

Gabre, R.M., F.K. Adham, and H. Chi. 2005. Life table of Chrysomya megacephala (Fabricius) (Diptera: Calliphoridae). Acta Oecol. 27:179-183. 
Gotoh, T., A. Tsuchiya, and Y. Kitashima. 2006. Influence of prey on developmental performance, reproduction and prey consumption of Neoseiulus californicus (Acari: Phytoseiidae). Exp. Appl. Acarol. 40:189-204.

Hosseini, M., B. Hatami, A. Savoir, H. Allahyari, and A. Ashouri. 2005. Predation by Allothrombium pulvinum on the spider mites Tetranychus urticae and Amphitetranychus viennensis: predation rate, prey preference and functional response. Exp. Appl. Acarol. 37:173-181.

INE. 2007. Instituto Nacional de Estadística, Santiago, Chile. Available at http://www.censoagropecuario. cl/noticias/07/11/files/10.xls (Accessed 11 December 2007).

Kerguelen, V., and M. Hoddle. 2000. Comparison of the susceptibility of several cultivars of avocado to the persea mite, Oligonychus perseae (Acari: Tetranychidae). Sci. Hortic. (Canterbury, Engl.) 84:101-114.

Kishimoto, H. 2003. Development and oviposition of predacious insects, Stethorus japonicus (Coleoptera: Coccinellidae), Oligota Kashmirica benefica (Coleoptera: Staphylinidae), and Scolothrips takahashii (Thysanoptera: Thripidae) reared on different spider mite species (Acari: Tetranychidae). Appl. Entomol. Zool. 38:15-21.

Kishimoto, H., and K. Takagi. 2001. Evaluation of predation on Panonychus citri (McGregor) (Acari: Tetranychidae) from feeding traces on eggs. Appl. Entomol. Zool. 36(1):91-95.

Kontodimas, D.C., P.G. Milonas, G.J. Stathas, L.P. Economou, and N.G. Kavallieratos. 2007. Life table parameters of the pseudococcid predators Nephus includens and Nephus bisignatus (Coleoptera: Coccinellidae). Eur. J. Entomol. 104:407-415.

La Rossa, R., y N. Kahn. 2003. Dos programas de computadora para confeccionar tablas de vida de fertilidad y calcular parámetros biológicos y demográficos en áfidos (Homoptera: Aphidoidea). RIA (Argentina) 32(3):127-142.

Maia, A.H., A.J. Luiz, and C. Campanhola. 2000. Statistical inference on associated fertility life table parameters using Jackknife technique: Computational aspects. J. Econ. Entomol. 93(2):511-518.

Matos, C.H., A. Pallini, F.F. Chaves, and C. Galbiati. 2004. Domácias do cafeeiro beneficiam o ácaro Predador Iphiseiodes zuluagai Denmark and Muma (Acari: Phytoseiidae)? Neotrop. Entomol. 33(1):057-064.

Meyer, J.S., C.G. Ingersoll, L.L. McDonald, and M.S. Boyce. 1986. Estimating uncertainty in population growth rates: Jackknife vs. bootstrap techniques. Ecology 67(5):1156-1166.
Naranjo, S.E. 2001. Conservation and evaluation of natural enemies in IPM systems for Bemisia tabaci. Crop Prot. 20:835-852.

Nishida, R. 2002. Sequestration of defensive substances from plants by lepidoptera. Annu. Rev. Entomol. 47:57-92.

Nomikou, M., R. Meng, R. Schraag, M.W. Sabelis, and A. Janssen. 2005. How predatory mites find plants with whitefly prey. Exp. Appl. Acarol. 36:263-275.

Obrycki, J.J., and T.J. Kring. 1998. Predaceous Coccinellidae in biological control. Ann. Rev. Entomol. 43:295-321.

Oliveira, R.C., L.F. Alves, e P.M. Neves. 2001. Técnica para desenvolvimento de bioensaios com Oligonychus yothersi (Acari: Tetranychidae) em laboratório. Arq. Inst. Biol., São Paulo 68(2):125-126.

O’Neil, R.J., K.L. Giles, J.J. Obrycki, D.L. Mahr, J.C. Legaspi, and K. Katovich. 1998. Evaluation of the quality of four commercially available natural enemies. Biol. Control 11:1-8.

Ozman-Sullivan, S.K. 2006. Life history of Kampimodromus aberrans as a predator of Phytoptus avellanae (Acari: Phytoseiidae, Phytoptidae). Exp. Appl. Acarol. 38:15-23.

Palevsky, E., Y. Maoz, S. Gal, Y. Argov, M. Zilberstein, M. Noy, Y. Izhar, y V. Alchanatis. 2007a. Establecimiento de un umbral de acción para el ácaro de la palta. p. 46. In VI Congreso Mundial de la Palta, Viña del Mar, Chile. 12-16 de noviembre de 2007. Comité de Paltas y Pontificia Universidad Católica de Valparaíso, Viña del Mar, Chile.

Palevsky, E., Y. Maoz, S. Gal, Y. Argov, M. Berkeley, M. Zilberstein, et al. 2007b. Potenciales depredadores nativos y exóticos para el control biológico de la reciente introducción del ácaro de la palta, Oligonychus perseae en huertos de palto en Israel. p. 49. In VI Congreso Mundial de la Palta, Viña del Mar, Chile. 12-16 de noviembre de 2007. Comité de Paltas y Pontificia Universidad Católica de Valparaíso, Viña del Mar, Chile.

Persad, A., and A. Khan. 2002. Comparison of life table parameters for Maconellicoccus hirsutus, Anagyrus kamali, Cryptolaemus montrouzieri and Scymnus coccivora. Biocontrol 47:137-149.

Rabinovich, J.E. 1980. Introducción a la ecología de poblaciones animales. 313 p. Editorial Continental, México.

Ragusa, S., and R. Vargas. 2002. On some phytoseiid mites (Parasitiformes: Phytoseiidae) from Chile. Phytophaga 12:129-139. 
Ragusa, S., R. Vargas, H. Tsolakis, and R. Ashbach. 2000. Laboratory studies on the influence of various food substances on some biological and lifetable parameters of Cydnodromus picanus Ragusa (Parasitiformes: Phytoseiidae) associated with Citrus trees in the Chilean desert. Phytophaga 10:11-23.

Reis, P.R., A.V. Teodoro, M.P. Neto, and E.A. Da Silva. 2007. Life history of Amblyseius herbicolus (Chant) (Acari: Phytoseiidae) on coffee plants. Neotrop. Entomol. 36(2):282-287.

SAG. 2007. Servicio Agrícola y Ganadero, Santiago, Chile. Available at http://www2.sag.gob.cl/reqmercado/ consulta_agricola.asp (Accessed 11 December 2007).

SAS Institute. 2007. SAS system for Windows 2000, version 8.2. SAS Institute, Cary, North Carolina, USA.

Schaffer, B., J. Peña, S.P. Lara, and D. Buisson. 1986. Net photosynthesis, transpiration, and stomatal conductance of avocado leaves infested by avocado red mites. Proc. Interamerican Soc. Tropical Hortic. 30:73-77.

Shrewsbury, P.M., and M.R. Hardin. 2003. Evaluation of predatory mite (Acari: Phytoseiidae) releases to suppress spruce spider mites, Oligonychus ununguis (Acari: Tetranychidae), on Juniper. J. Econ. Entomol. 96(6):1675-1684.

Steel, R., y J.H. Torrie. 1985. Bioestadística: principios y procedimientos. 622 p. McGraw-Hill, Santafé de Bogotá, Colombia.

Takano-Lee, M., and M.S. Hoddle. 2002. Oligonychus perseae (Acari: Tetranychidae) population responses to cultural control attempts in an avocado orchard. Fla. Entomol. 85(1):216-226.

Termonia, A., J.M. Pasteels, D.M. Windsor, and M.C. Milinkovitch. 2001. Dual chemical sequestration: a key mechanism in transitions among ecological specialization. Proc. R. Soc. London, Ser. B 269:1-6.
Tixier, M., S. Kreiter, B. Cheval, S. Guichou, P. Auger, and R. Bonafos. 2006. Immigration of phytoseiid mites from surrounding uncultivated areas into a newly planted vineyard. Exp. Appl. Acarol. 39:227-242.

Trigo, J.R. 2000. The chemistry of antipredator defense by secondary compounds in Neotropical lepidoptera: Facts, perspectives and caveats. J. Braz. Chem. Soc. 11(6):551-561.

Vantornhout, I. 2006. Biology and ecology of the predatory mite Iphiseius degenerans (Berlese) (Acari: Phytoseiidae). 207 p. Ph.D. thesis. Ghent University, Ghent, Belgium.

Vantornhout, I., H. Minnaert, L. Tirry, and P. De Clercq. 2005. Influence of diet on life table parameters of Iphiseius degenerans (Acari: Phytoseiidae). Exp. Appl. Acarol. 35:183-195.

Yang, T., and H. Chi. 2006. Life tables and development of Bemisia argentifolii (Homoptera: Aleyrodidae) at different temperatures. J. Econ. Entomol. 99(3):691698.

Yu, J., H. Chi, and B. Chen. 2005. Life table and predation of Lemnia biplagiata (Coleoptera: Coccinellidae) fed on Aphis gossypii (Homoptera: Aphididae) with a proof on relationship among gross reproduction rate, net reproduction rate, and preadult survivorship. Ann. Entomol. Soc. Am. 98(4):475-482.

Zhu-Salzman, K., D.S. Luthe, and G.W. Felton. 2008. Arthropod-inducible proteins: Broad spectrum defenses against multiple herbivores. Plant Physiol. 146:852-858. 